\title{
Trabalhos selecionados de VIII GeoSciEd 2018 / VIII EnsinoGEO-2018
}

Selected papers of VIII GeoScied 2018 / VIII EnsinoGEO-2018

Correspondência

Os editores

Terre Didatica

Instituto de Geociências

Caixa Postal (P.O. Box) 6152

Rua Carlos Gomes 250,

13083-855 Campinas, SP, Brasil

E-mail: terraedidatica@ige.unicamp.br 


\section{Trabalhos selecionados de VIII GeoSciEd 2018 / VIII EnsinoGEO-2018}

A Sociedade Brasileira de Geologia apoiou a comunidade brasileira de Educação em Geociências ao promover, em paralelo, duas conferênciasna cidade de Campinas SP, em julho de 2018. Terra Didatica reune trabalhos selecionados de ambos os eventos, que são publicados a partir da página 256 deste número e ocuparão grande parte do próxima número. O tema geral - Geociências para todos - orientou os trabalhos da $8^{\text {th }}$ Quadrennial Conference of the International Geoscience Education Organisation (IGEO) / VIII GeoSciEd 2018 - e do VIII Simpósio Nacional de Ensino e História de Ciências da Terra / EnsinoGEO-2018.

A contribuição abrangente de especialistas, pesquisadores, professores, estudantes e outros interessados nesses campos corresponde a um total de 290 trabalhos científicos. Dois terços dos trabalhos expostos correspondem ao EnsinoGEO-2018, fato que assinala a enorme disposição da comunidade nacional em mostrar aos colegas brasileiros e do exterior o progresso e o alcance de suas pesquisas. Embora algumas edições anteriores do EnsinoGEO tenham publicado anais com trabalhos completos, os anais com trabalhos completos da conferência GeoSciEd são publicados pela primeira vez. Participantes oriundos de África do Sul, Alemanha, Argentina, Austrália, Canadá, Chile, França, Índia, Inglaterra, Irlanda, Itália, Japão, Marrocos, Paraguai, Reino Unido, República da Coreia e USA que viajaram até aqui experienciaram calorosa recepção. A comunidade nacional teve presença decisiva em todas as atividades e reuniões. Gostaríamos de registrar algumas metas, parcial ou plenamente atingidas:

1. Fortaleceram-se durante o evento os laços da comunidade nacional com pesquisadores das três Américas. Em Johannesburgo, no ano 2010, cogitou-se compor uma rede latino-americana de Educação em Geociências. Vislumbramos a formação de uma rede de cooperação internacional das Américas do Sul e Central, capaz de ultrapassar iniciativas meramente individuais e fomentar mecanismos de representação institucional, envolvendo universidades, centros de pesquisa e associações científicas.

2. Durante o evento, tomaram posse os membros da Comissão de Ensino Médio (COGEM) da Sociedade Brasileira de Geologia, dando início a um trabalho de fôlego destinado a aumentar a presença das Ciências da Terra na educação básica brasileira.

O tema central das duas conferências (Geociências para todos) assume, neste momento singular, o sentido mais amplo de uma educação como - processo de constante libertação do homem -, no sentido exato formulado por Paulo Freire, o grande educador brasileiro ${ }^{1}$. O conhecimento geocientífico promove a autonomia do pensamento, a visão crítica e a construção de valores e práticas socioculturais que ajudam a traçar o caminho da sustentabilidade. Esperamos que o intercâmbio proporcionado pelas reuniões e debates em Campinas tenham disseminado essa visão estratégica e ajudado a abolir a cultura do individualismo narcísico e da competição desenfreada, que causam rupturas no tecido social, em lugar de promover a cooperação e o entendimento entre as pessoas.

Os Editores,

Celso Dal Ré Carneiro

Pedro Wagner Gonçalves

Rosely Aparecida Liguori Imbernon

Fabio Braz Machado

Cassio Angelo Dalcin Cerri

1 Freire P. 1983. Extensão ou comunicação? Trad. R.D. Oliveira. 7 ed. Rio de Janeiro, Paz e Terra. 93p. (O Mundo, Hoje, v. 24). 


\section{Selected papers of VIII GeoSciEd 2018 / VIII EnsinoGEO-2018}

The Brazilian Society of Geology has recently published the annals of two conferences held in Campinas in July 2018 - the $\mathbf{8}^{\text {th }}$ Quadrennial Conference of the International Geoscience Education Organization (IGEO), parallel to the VIII National Symposium on Teaching and History of Earth Sciences / EnsinoGEO-2018. Starting from the page 256 of this issue and covering great part of the forthcoming edition, Terra Didatica include few selected papers from $8^{\text {th }}$ GeoSciEd 2018 and EnsinoGEO-2018, under the umbrella of "Geosciences for all".

The contribution of specialists, researchers, professors, students and other interested in these fields comprised 290 scientific papers. Two-thirds of them correspond to EnsinoGEO-2018, a fact that indicates the enormous willingness of the national community to show Brazilian and foreign colleagues the progress and scope of their research. Although some previous editions of EnsinoGEO have published annals with full papers, by the first time a volume of proceedings with complete papers from GeoSciEd conference is published. Participants from Argentina, Australia, Canada, Chile, France, India, England, Germany, Ireland, Italy, Japan, Morocco, Paraguay, Republic of Korea, South Africa, United Kingdom, and USA have experienced warm welcome. The national community had a decisive presence in all activities and meetings. We would like to record two relevant steps:

1. The ties of the national community with researchers from the three Americas were strengthened during the event. In Johannesburg, in 2010, a Latin American network of Geosciences Education was envisaged. We can now consider to make a network of international cooperation in South and Central America. The intention is to go beyond purely individual initiatives, and to foster institutional representation mechanisms, by means of the staff from universities, research centers and scientific associations.

2. During the event, members of the Education Commission for High School level (COGEM) of the Brazilian Society of Geology started their work, aimed to increase the presence of Earth Sciences in Brazilian basic education.

The central theme of the conferences expands the meaning of education as "a process of constant liberation of man", in the exact sense formulated by Paulo Freire, the great Brazilian educator. The knowledge on Geosciences promotes autonomy of thinking, critical vision and construction of sociocultural values and practices that help to chase the path of sustainability. We hope that Terre Didatica helps to disseminate this strategic vision and to discard a certain culture of narcissistic individualism and competition that causes ruptures in the social tissue, instead of promoting cooperation and understanding among people.

The Editors,

Celso Dal Ré Carneiro

Pedro Wagner Gonçalves

Rosely Aparecida Liguori Imbernon

Fabio Braz Machado

Cassio Angelo Dalcin Cerri 